\title{
ABOUT INFLUENCE OF LINE BLANKETING ON INTENSITIES OF FeI LINES CALCULATED UNDER NLTE APPROACH
}

\author{
U. Sh. Bayazitov \\ Bashkir State University, Sibay Branch of Bashkir Academy of Sci., \\ 12 Lenin Str., Sibay, Russia \\ e-mail: bayazit@mail.ru,bus@bashnet.ru \\ (Received July 22, 2002)
}

\begin{abstract}
We have modeled line blanketing effect on intensities of FeI lines. We have taken into account $\mathrm{H}$, CaI, CaII, CaIII, SiI, SilI, MgI, MgII spectral lines. Totally more then 3000 spectral lines have been included. It is shown that with decreasing effective temperature the line blanketing effect increases. The ignoring of line blanketing can lead to an error of estimation of iron abundance more than 0.02 dex for the Sun and solar type stars. Our preliminary results with a limited number of spectral lines and atoms show the importance of the line blanketing effects for intensities of FeI lines in the atmosphere of cool stars.
\end{abstract}

Key words: Sun, stars: atmospheres, abundances, lines blanketing.

PACS number(s): 96.60.Tf

Iron is a widely spread element in Universe. Iron atoms contribute strongly to line blanketing and electron pressure in the atmospheres of the Sun and solar type stars. Many Fe spectral lines are used for determination of global stellar parameters such as gravity, rotation velocities, effective temperatures, etc. We also use these lines to solve some problems of the stellar astrophysics, namely:

- precise determination of iron abundance in Sun and stars;

- determination of metallisity for stars with extrasolar planets;

- construction semiempirical chromosphere models for solar flares (collaboration with E. Baranovsky, Crimean Astroph. Observatory);

- determination of Fe abundance in double stars with great eccentricities (collaboration with V. Leushin, Special Astroph. Observatory).

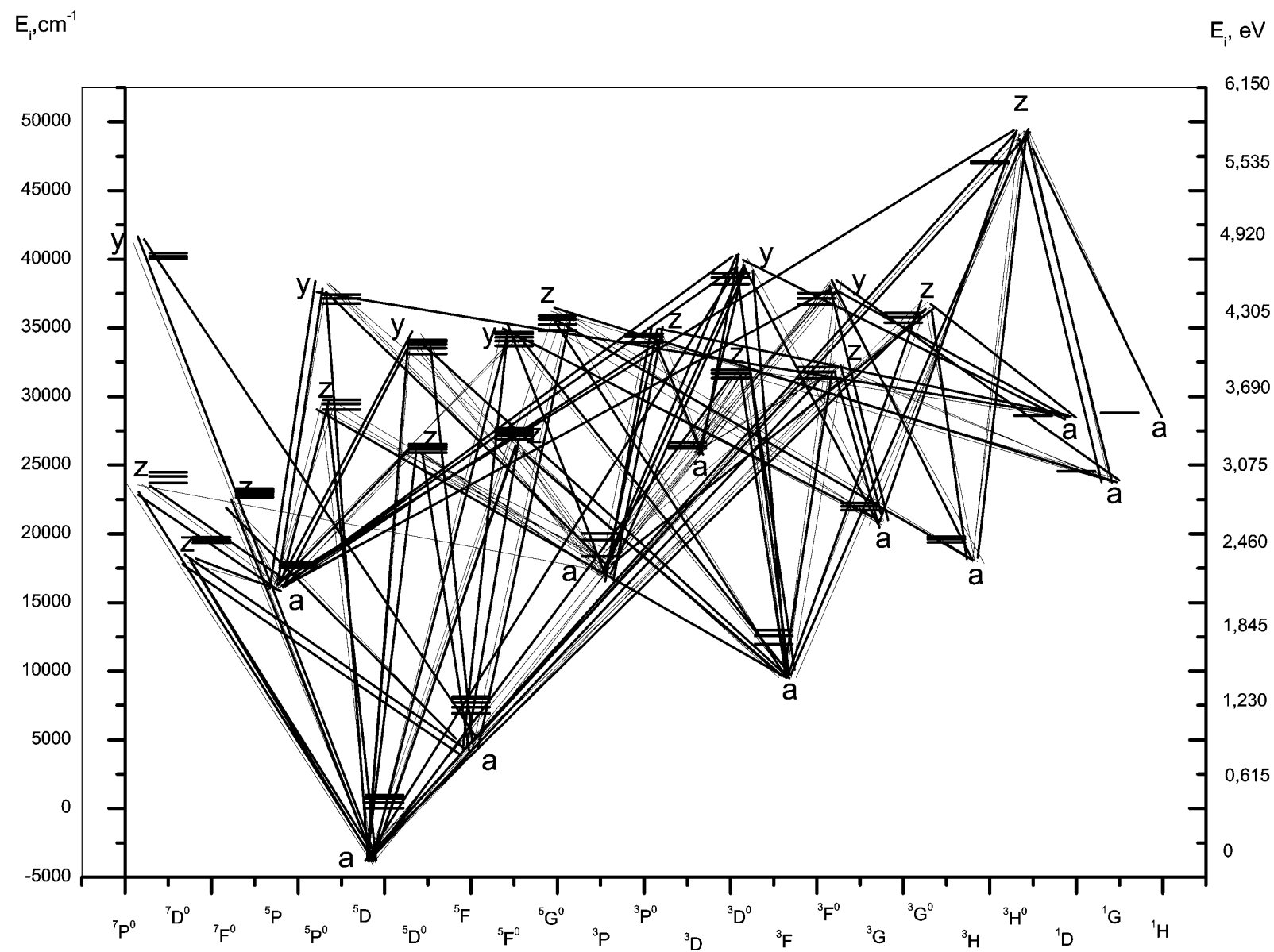

Fig. 1. 100-level iron atom model. 
For solving these problems we use computer code MULTY [1] and stellar atmosphere models of R. Kurucz [2]. For our study we have constructed 100-level iron atom model (Fig. 1). This model includes 99 FeI levels and one FeII level. We have taken in to account 506 bound-bound transitions. In general, it has been included more then 4000 transitions. Since the pioneer work of Athay and Lites [3] it is well known that the photoionization processes plays the major role in NonLTE effects in FeI lines formation in stellar atmospheres. For this reason, the photoionization cross-sections must be treated with high accuracy. We have used the data from IRON project [4]. The dependence of iron photoionization cross-sections on wavelengths is very complex (see Fig. 2). Also, the radiation field on iron photoionization frequencies is not a smooth function because the continuum is superimposed by a great number of spectral lines for the late type stars and the Sun, especially for wavelengths shorter then $4000 \AA$. Fig. 3 shows the influence of line blending on the continuum flux in the Sun, Arcturus and Procyon using models from [2].

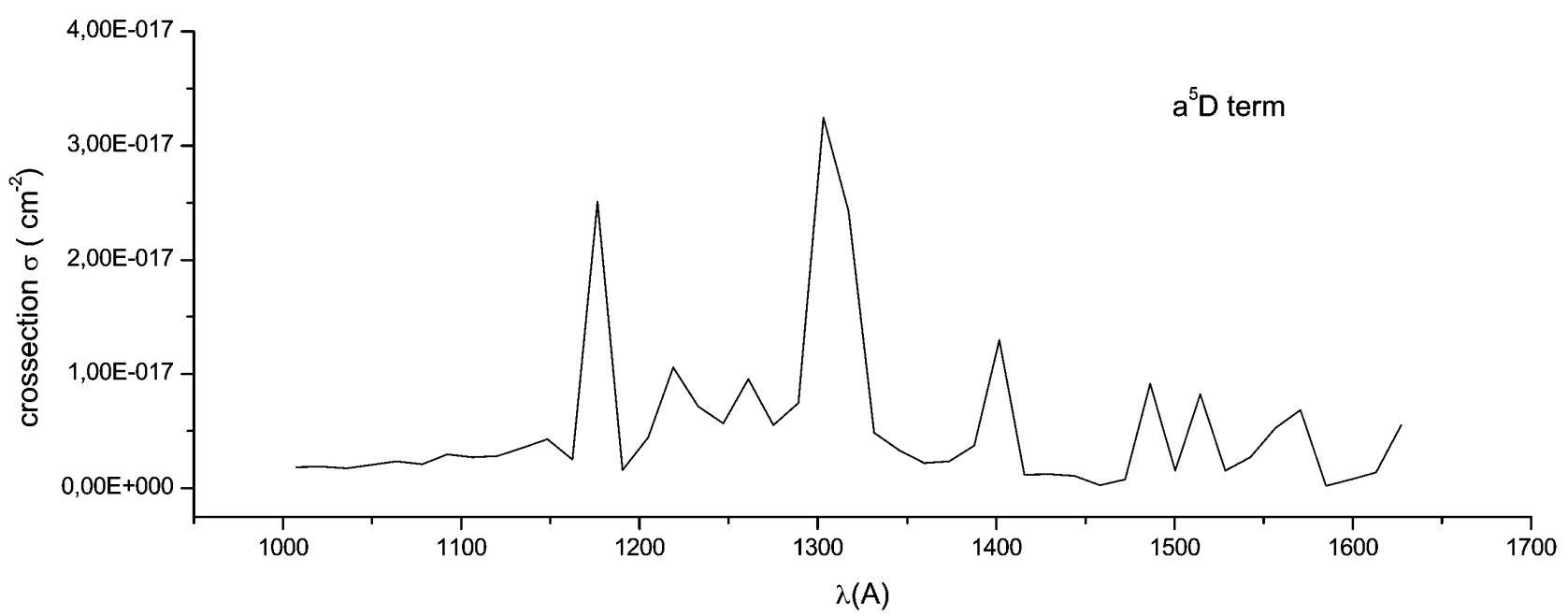

Fig. 2. Photoionization cross-sections as a function of wavelength for the a5D FeI term.

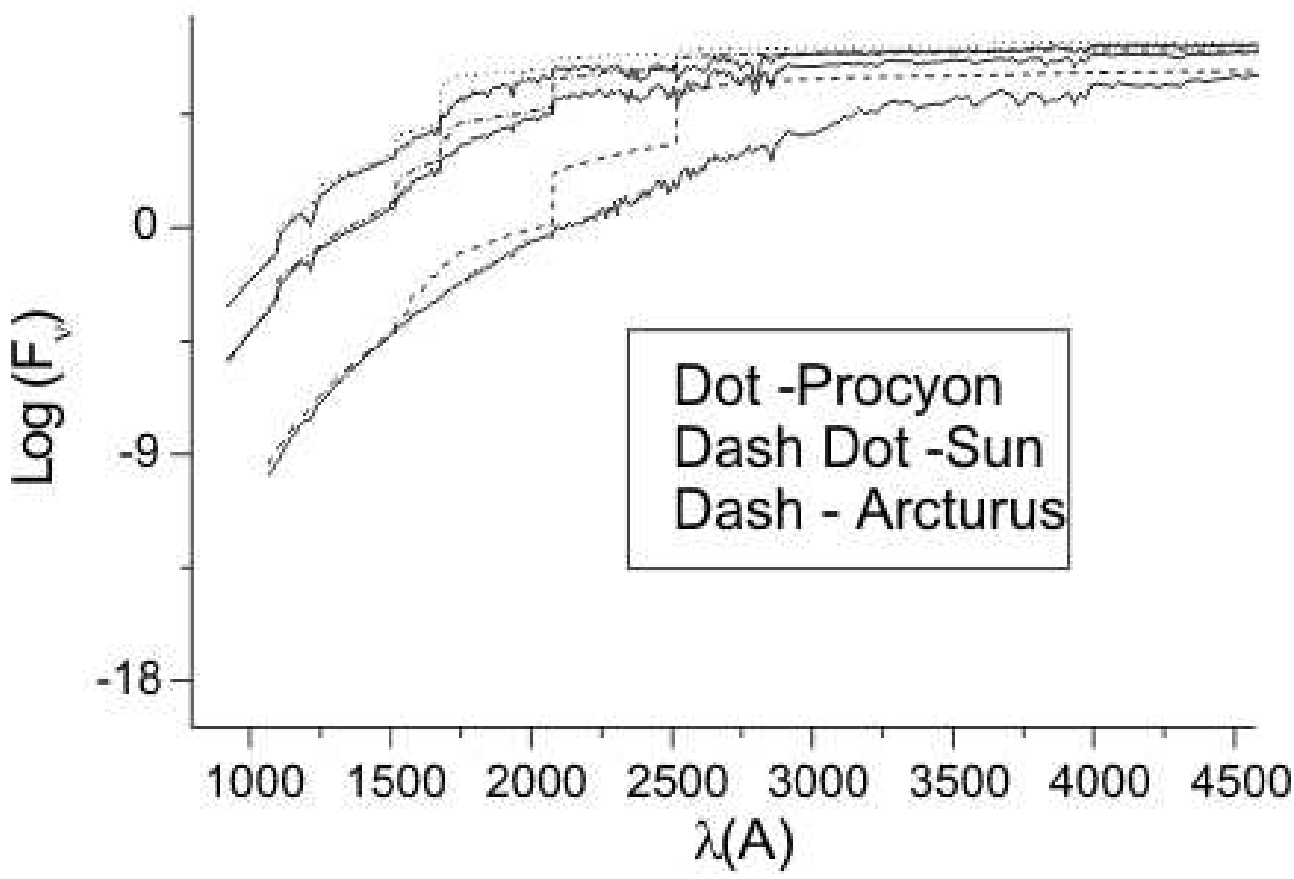

Fig. 3. The influence of line blanketing on the continuum fluxes of the Sun, Arcturus and Procyon 
How does the line blanketing affect the FeI lines intensities in the objects investigated by us? To answer to this question we have modeled this effect in our NonLTE calculations. For this purpose we have used a procedure ABSLIN from MULTY code. We have treated the line blanketing from H, CaI, CaII, CaIII, SiI, SiII, MgI, MgII spectral lines. Atomic data for these elements has been taken from VALD database. Totally, more then 3000 spectral lines have been included. Also, we have consider the influence of the diatomic molecules such as $\mathrm{CO}, \mathrm{CH}$, etc. Atmosphere models for the Sun, Arcturus and Procyon have been taken from [2]. We have obtained the following results:

- with decreasing effective temperature the line blan- keting effect increases;

- for Arcturus the calculated FeI equivalent widths increased more than 2 percent. For the Sun and Procyon these values were $1.5 \%$ and $1 \%$, respectively;

- from 506 carefully calculated spectral lines 32 lines (for Arcturus) and 6 lines (for the Sun and Procyon) changed intensities more then two times;

- the ignoring of line blanketing may lead to an error of estimation of the iron abundance more than $5 \%$ for the Sun and the solar type stars;

- our preliminary results with a limited number of spectral lines and atoms show the importance of the line blanketing effects for intensities of FeI lines in the atmosphere of cool stars.
[1] M. Carlsson. Uppsala Astron. Obs. Spec. Rep. N. 33, P. 1-33 (1986).

[2] R. Kurucz. CD-roms. N. 18 (1994).
[3] R. Gr. Athay, B. W. Lites, Astrophys. J. 176, 809 (1972).

[4] M. A. Bautista, Astron. Astrophys. Suppl. Ser. 122, 167 (1997).

\title{
ПРО ВПЛИВ БЛАНКЕТУВАННЯ ЛІНІЯМИ НА ІНТЕНСИВНОСТІ ЛІНІӤ FеІ, РОЗРАХОВАНИХ У НАБЛИЖЕННІ БЕЗ ЛОКАЛЬНОЇ ТЕРМОДИНАМІЧНОЇ РIВНОВАГИ
}

\author{
У. III. Баязітов \\ Башкирсъкий державний університет, Сібайсъкий відділ Башкирсъкой академій наук, \\ вул. Леніна, 12, Сібай, Росіл
}

Промодельовано вплив ефекту бланкетування лініями на інтенсивність ліній FеI. Узято до уваги спектральні лінї Н, CaI, CaII, CaIII, SiI, SiII, MgI, MgII. Сумарно включено більше ніж 3000 спектральних ліній. Показано, що зі зменшенням ефективної температури бланкетування зростає. Неврахування ефекту бланкетування може призвести до помилки в оџінші вмісту заліза більше ніж 0.02 dex для Соншя $\mathbf{i}$ зір сонячного типу. Наші попередні результати з обмеженою кількістю спектральних ліній і атомів показують важливість урахування бланкетування лініями на інтенсивність ліній FeI в атмосфері холодних зір. 